\title{
THE POSSIBILITY STUDY OF BRIQUETTING AGRICULTURAL WASTES FOR ALTERNATIVE ENERGY
}

\author{
Gunjan Patil \\ Department of Forestry, Wildlife and Environmental Sciences \\ Guru Ghasidas Vishwavidyalaya Bilaspur-495009, India
}

Received: 11 December 2018, Revised: 15 October 2019, Accepted: 28 October 2019

\begin{abstract}
THE POSSIBILITY STUDY OF BRIQUETTING AGRICULTURAL WASTES FOR ALTERNATIVE ENERGY. Globally energy crisis is known as a new era's biggest problem. The use of agricultural wastes into the form of briquettes are the best alternative option of renewable energy sources. This paper studies the possibility of utilizing agricultural wastes into briquetting production with high calorific value. Major wastes were sugarcane bagasse, coffee husk, wheat straw, peanut shells, rice husks, paddy straw, corn stalks, sunflower stalk, soybean husk, coir pitch, jute sticks, caster seed shells, mustard stalks, cotton stalks and tobacco wastes for energy in the form of briquettes biomass. Observations were taken from Department of Bioenergy, Tamil Nadu Agriculture University, Coimbatore (Tamil Nadu), India of different raw materials and briquettes of those raw materials. Results show that there were very satisfactory results after evaluation. In general, calorific value briquettes is higher than those of raw materials. Raw materials of agricultural wastes and forest residual wastes ranged from 1,200-3,000 Kcal/ $\mathrm{Kg}$ and its calorific values are significantly higher in briquettes than raw materials. Raw material of rice husk produces $3,000 \mathrm{Kcal} / \mathrm{kg}$ and briquettes of rice husk produces $3200 \mathrm{Kcal} / \mathrm{kg}$. Likewise differences were observed in all types of agricultural wastes. The input and output ratio ware observed as cost-effective and profitable in all parameters for the farmers. Briquetting production is the emerging, ecofriendly, cost effective and profitable technology for the use of agricultural residues. It may help farmers to improve its socio-economic status and proper reuses of agricultural wastes.
\end{abstract}

Keywords: Briquetting, reuse, agricultural wastes, biomass, calorific value

STUDI PEMANFAATAN BRIKET LIMBAH PERTANLAN SEBAGAI ENERGI ALTERNATIF. Krisis energi global dikenal sebagai masalah terbesar di era baru. Penggunaan limbah pertanian dalam bentuk briket adalah piliban alternatif terbaik dari sumber energi terbarukan. Tulisan ini mempelajari kemungkinan pemanfaatan limbah pertanian menjadi produksi briket dengan nilai kalor tinggi. Limbah utama yaitu ampas tebu, sekam kopi, jerami gandum, kulit kacang, sekam padi, jerami padi, tangkai jagung, tangkai bunga matahari, kulit kedelai, sabut kelapa, tongkat rami, kulit biji kastor, tangkai mustard, batang kapas dan limbah tembakan untuk energi dalam bentuk biomassa briket. Pengamatan dilakukan pada berbagai bahan baku dan briket bahan baku tersebut di Departemen Bioenergi, Universitas Pertanian Tamil Nadu, Coimbatore (Tamil Nadu), India. Penelitian menunjukkan adanya hasil yang sangat memuaskan setelab evaluasi perbedaan antara nilai kalor baban baku dan briket bahan baku tersebut. Baban baku limbah pertanian dan sisa limbah hutan berkisar 1.200-3.000 Kkal/Kg. Setelah dilakukan evaluasi, hasil pengamatan menunjuk.kan perbedaan siginifikean antara nilai kalor briket dan nilai kalor bahan baku. Bahan baku sekam padi menghasilkan 3000 $\mathrm{Kkal} / \mathrm{Kg}$ dan briket sekam padi menghasilkan $3.200 \mathrm{Kkal} / \mathrm{Kg}$. Demikian juga perbedaan diamati pada semua jenis limbah pertanian. Rasio output input diamati sebagai biaya efektif dan menguntungkan di semua parameter untuk petani. Produksi briket adalah teknologi yang muncul, ramah lingkungan, hemat biaya, dan menguntungkan untuk penggunaan residu pertanian. Pemanfaaan briket limbah pertanian dapat membantu petani untuk meningkatkan status sosial ekonomi dan penggunaan kembali limbah pertanian dengan tepat.

Kata kunci: Briket, penggunaan kembali, limbah pertanian, biomas, nilai kalor

*Corresponding author: gunju_2007@yahoo.com 


\section{INTRODUCTION}

Economic growth, industrialization and growing population in the developing countries of Asia contribute to a rapidly growing demand for energy in the region while global environmental concerns call for limiting use of fossil fuels (Sainu et al., 2017). Production of biomass and biofuels are growing industries as interest in sustainable fuel sources is growing (Obi et al., 2013). In the present era facing the problems of price hike of liquid fuels, especially furnace oil are growing at steeper rate than solid fuel price, substitution of furnace oil to solid briquette is one of the alternative Renewable Energy Technologies.

Renewable Energy Technologies present a viable option of meeting the growing energy demand, especially in remote and rural areas (Patil et al., 2012). In the last decades, renewable energy sources are preferred, e.g. wind energy, water energy, solar energy and biomass energy. The effort results of more extensive utilization of the wind energy and solar energy are not conclusive in the conditions. But the utilization of the biomass energy appears as the perspective (Brozek et al., 2012). The process involves conversion of low density bio mass waste to high density bio mass fuel called briquettes. The more replicable, appropriate, cost effective, locally available, easy to make, environment friendly and culturally fitting a technology is for the briquetting of biomass, the higher its chance of success (Hood, 2010).

Briquettes have replaced the use of conventional and non-renewable fuels such as coal, wood, fossil fuel and others. This technology does not involve use of any kind of harmful chemical, which on burning emits poisonous gasses or smoke. Farmers are facing the problems related to proper disposal of agricultural wastes in to proper place. Most rural communities lack access to electricity and the cost of electricity is also unaffordable to the rural people. Energy usage by rural dwellers has been mainly for cooking or heating applications (Obi, 2014). Briquetting works on the natural phenomenon, which includes use of natural binder. Every bio mass contain a solid substance named lignin, which is when subjected to heavy pressure and heat gets converted into liquid, which binds the waste to produce high density bio mass fuel. A briquette is a block of flammable matter which is used as fuel to start and maintain a fire (Surajo \& Mustapha, 2017)

Compaction of bulky combustible materials for fuel making purposes has been a technology widely used by many countries. There have been several researches carried out on production of fuel briquettes for both domestic cooking and industrial applications. One of the major driving forces behind these researches is the need to address the environmental consequences and health hazards associated with the use of solid fuels and also an effective means of managing agro wastes. Among the common types of briquettes widely used in some countries are biomass briquettes, coal briquettes and charcoal briquettes, etc. However, more recently, it has been shown that blending coal and biomass (agro wastes) gives rise to a briquette with better combustion properties and pollutant emission compare to the conventional coal briquette (Raju et al., 2014).

A number of companies in India have switched from furnace oil to briquettes to save costs on boiler fuels. The use of briquettes is predominant in the southern parts of India, where coal and furnace oil are being replaced by briquettes. A number of units in North India are also using biomass briquettes as boiler fuel. Use of biomass briquettes can earn Carbon Credits for reducing emissions in the atmosphere. Briquettes also provide more calorific value/ $\mathrm{kg}$ and save around $30-40 \%$ of boiler fuel costs (3e Savers India LLP, 2018). Billions of tons of agricultural residue are generated each year in the developing and developed countries.

This volume of biodegradable wastes can be converted to an enormous amount of energy and raw materials. Agricultural biomass waste converted to energy can substantially displace fossil fuel, reduce emissions of greenhouse gases and provide renewable energy to people in developing countries, which is still lack of 
access to electricity. As raw materials, biomass wastes have attractive potentials for large-scale industries and community-level enterprises (Quartey, 2011). Most of the agricultural wastes are used in production of briquettes. Briquettes are eco-friendly renewable source of energy and avoid adding fossil carbon to the atmosphere. Objective of the study was to analyse the calorific value of briquettes, which may help to use of agricultural wastes in proper way. Biomass briquetting production may be the good alternate energy source in the future.

\section{MATERIAL AND METHOD}

\section{A. Study Site and Raw Material}

Study was carried out at Forest College and Research Institute, Mettupalayam, Tamil Nadu Agriculture University, India and College of Agriculture, Coimbatore, Tamil Nadu Agriculture University, India. A Briquetting unit was installed in FC and RI during 2009, which is running regularly. All type of forest and agricultural waste were the major raw materials used for the briquetting production. These were collected from industries around Mettupalayam to run the machinery. The process of compaction of residues into a product of higher density than the original raw material is known as densification or briquetting. Densification has aroused a great deal of interest in developing countries all over the world lately as a technique for upgrading of residues as energy sources. Following raw materials were used to production of briquettes (Table 1 and Figure 1) (Tripathy et al., 1998).

\section{B. Method}

Following steps were adopted to prepare briquettes at the department.

1. Drying: Drying is essential part of briquetting production as per used raw material. A moisture content of $8-12 \%$ is normally ideal for agricultural wastes and wood densification. The maximum allowance of moisture content in mechanical piston presses is $15 \%$, whereas hydraulic systems can handle moisture contents up to 15-30 $\%$, depending on design of machine. Used model was Random Piston Type model.

2. Comminuting (sizing raw material): The raw material used in production of briquettes must be of a suitable particle size before it enters the densification process. The particle size should not exceed $25 \%$ of the diameter of the final product for most densification equipments (Bhattacharya, 1989). Forest

Table 1. Listed below are some of the materials used during formulating briquettes

\begin{tabular}{cccc}
\hline Sugarcane bagasse & Coffee husk & Wheat straw & Peanut shells \\
Rice husks & Paddy straw & Corn stalks & Sunflower stalk \\
Groundnut shells & Rise husks & Castor husks & Coffee bean husks \\
Soybean husk & Coir pitch & Jute sticks & Caster seed shells \\
Mustard stalks & Cotton stalks & Tobacco waste & Corn waste \\
Agro-forestry wastes & Barks & Leafs & Saw dusts \\
\hline
\end{tabular}
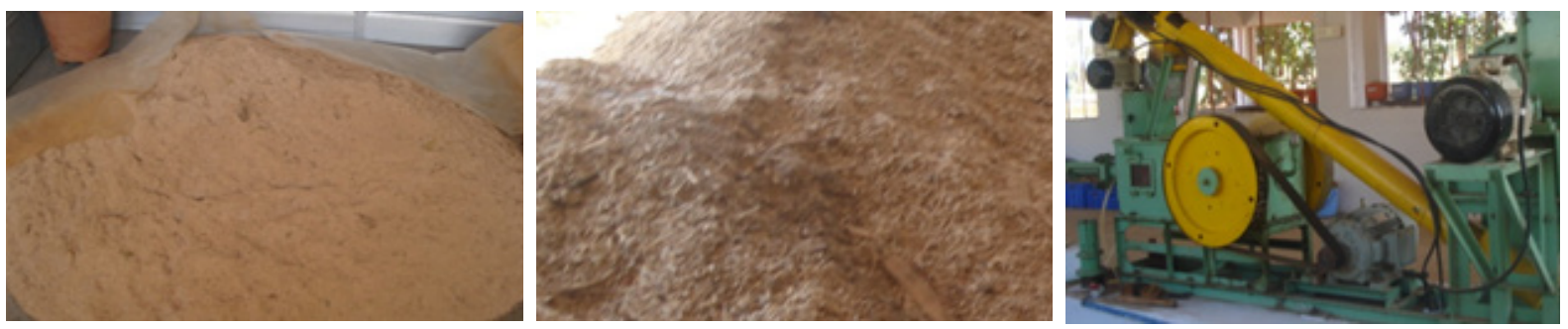

Figure 1. Raw material used to prepare briquettes and briquetting machine 
College \& Research Institute has briquetting machine with the capacity to produce of 250 $\mathrm{kg} / \mathrm{hr}$ briquettes and size of product is 30 $40 \mathrm{~mm}$ and another capacity is $500 \mathrm{~kg} / \mathrm{hr}$, the size of product is $50-60 \mathrm{~mm}$.

3. Conditioning: To make the raw material softer and easier to work within the densification process, superheated steam added in the stage between comminuting and densification (Hirsmark, 2002). A softer raw material contributes to binding the material together and results in briquettes that do not fall apart easily.

4. Densification: There are a few different technologies for production of briquettes; mechanical- or hydraulic piston press densification, screw press densification and roll press densification units.

5. Cooling: To allow the briquette to cool off in an optimal way, most piston press systems need a cooling track where the material slowly can drop in temperature before they fall apart into desired lengths ( 3 metre).

6. Storing and transporting: After cooling, the briquettes are normally stored before combustion. Storing may take place outdoor under roof, indoor, in container or in other ways. The transport from production unit to combustion is by truck and tractor.

7. Combustion: Most of the combustion plants for solid fuels can utilize briquettes. Industrial boilers though are most suitable for and convenient with the task. In the cases where the briquettes are turned into powder after transport to the heating plant, combustion takes place. Used model for briquetting production was Random Piston Type model (Figure 1).

8. Calorific Value: The calorific value was determined by using Oxygen bomb calorimeter in accordance with Standard Method by the Bioenergy Department, Tamil Nadu Agricultural University, and Coimbatore (Tamil Nadu) India. Calorimetry is the science of measuring quantities of heat, as distinct from "temperature". The instruments used for such measurements are known as calorimeters. The calorific value (heat of combustion) of a sample may be broadly defined as the number of heat units liberated by a unit mass of a sample when burned with oxygen in an enclosure of constant volume. In this reaction the sample and the oxygen are initially at the same temperature and the products of combustion are cooled to within a few degrees of the initial temperature; also the water vapor formed by the combustion is condensed to the liquid state. The initial and final temperatures are not the same - differing by the amount of temperature rise in the calorimeter - but the effect of this difference is small and usually it is neglected. Thus the term calorific value (or heat of combustion) as measured in a bomb calorimeter denotes the heat liberated by the combustion of all carbon and hydrogen with oxygen to form carbon dioxide and water, including the heat liberated by the oxidation of other elements such as sulfur which may be present in the sample (Parr Instrument Company, 2013).

\section{RESULT AND DISCUSSION}

Manufacturing process of briquettes has been carried out at Forest College and Research Institute, Mettupalayam (Tamil Nadu). Study was focused on use of agricultural wastes in efficient manner. All Calorific value of different raw material and briquettes from it has been taken from the department of Bioenergy, Tamil Nadu Agriculture University, Coimbatore (Tamil Nadu).

Calorific value of briquettes showed significant difference from their raw materials. The differences of Calorific value of briquettes from coconut husks and raw were found highest $1460 \mathrm{kcal} / \mathrm{kg}$ followed by paddy straw $1070 \mathrm{kcal} /$ $\mathrm{kg}$, groundnut shell $530 \mathrm{kcal} / \mathrm{kg}$ and sugar cane bagasse $384 \mathrm{kcal} / \mathrm{kg}$. The minimum differences were found in cotton husk $100 \mathrm{kcal} / \mathrm{kg}$. Table 
Table: 2. List of calorific value of raw agricultural waste and briquettes of it

\begin{tabular}{clccc}
\hline No. & Raw material & $\begin{array}{c}\text { Calorific value of raw } \\
\text { material }(\mathrm{kcal} / \mathrm{kg})\end{array}$ & $\begin{array}{c}\text { Calorific value of } \\
\text { briquettes }(\mathrm{kcal} / \mathrm{kg})\end{array}$ & $\begin{array}{c}\text { Calorific value Raw- } \\
\text { Briquettes }(\mathrm{kcal} / \mathrm{kg})\end{array}$ \\
\hline 1. & Rice husk & 3000 & 3200 & 200 \\
2. & Groundnut shell & 4000 & 4530 & 530 \\
3. & Cotton husks & 4400 & 4500 & 100 \\
4. & Coconut husks & 3500 & 4960 & 1460 \\
5. & Coir pitch & 3975 & 4150 & 175 \\
6. & Sunflower stalk & 4180 & 4300 & 120 \\
7. & Soya bean husk & 3990 & 4170 & 180 \\
8. & Sugarcane baggage & 3996 & 4380 & 384 \\
9. & Paddy straw & 2400 & 3470 & 1070 \\
10. & Tea waste & 4020 & 4237 & 217 \\
\hline
\end{tabular}
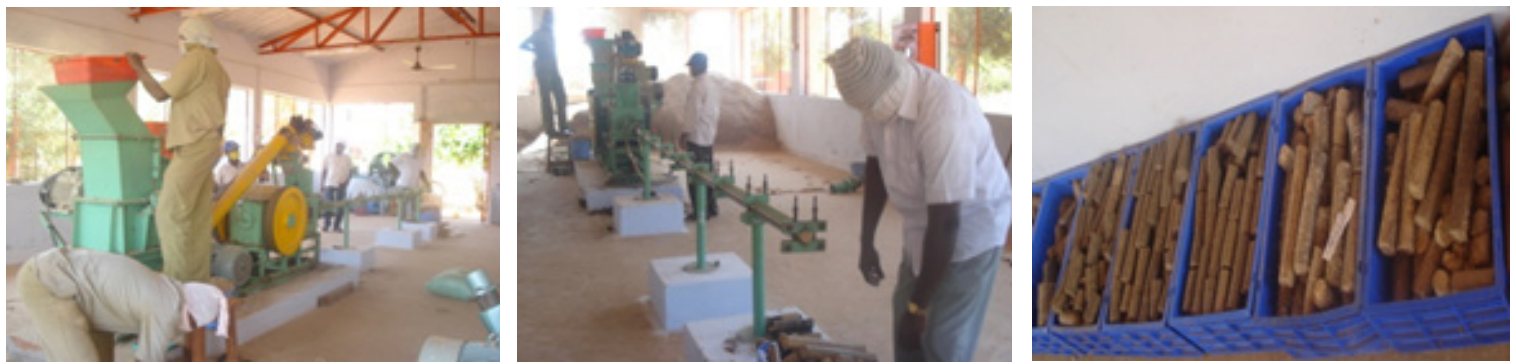

Figure 2. Processing of briquette into final product briquettes

2 showed very significant approach of use of agricultural wastes in briquetting production. Briquetting production may helps to increase the socio economic status of farmers.

Results were positive and good sign of use of agricultural wastes. Briquetting production is efficient technique for enhancement of livelihood of farmers (Patil et al., 2012). Briquettes were found higher calorific value than the raw material also observed by (Nurdin et al., 2018). Study was focused to recycle and reuse of wastes in ecofriendly manner. Wastes from different food based industries were used for fuel briquette production, which is a source of sustainable energy generation. It is environmentally friendly, cost effective and affordable compared to fossil fuel (Onukak et al., 2017). The calorific value of briquetted fuel shows that, the calorific value of combination 1 briquettes was found highest $(5154.58 \mathrm{kcal} / \mathrm{kg}$ ) and briquettes from combination 3 have least calorific value of $4188.64 \mathrm{kcal} / \mathrm{kg}$ (Sengar et al., 2012).

Agricultural waste covers a wide range of different species which show large variation in composition and fuel characteristics. However, the percentage composition of the combustible elements in the agricultural waste whether in loose form or briquette form are very low compare to fossil fuels. The calorific value is the energy released during combustion of unit mass of fuel. It forms the basis for determining the performance of energy system (Ioannis et al., 2016). Hence the low emissions of the oxides of the combustible elements. The composite rice husk and sawdust briquette has the highest theoretical Air- fuel ratio followed by composite groundnut shell and sawdust briquette (Nicholas, 2012). Manufacturing conditions such as temperature and pressure also influences calorific value (Tumuru, 2010). The briquetting of biomass material leads to increase 
net calorific value per unit volume, reduces transportation cost, improves bulk density and also improves handling characteristics. Study has supported to the scenario of renewable energy, the effects of calorific value to increase the efficiency of power generation (Shukla \& Vyas, 2015).

Briquetting of agricultural wastes/crop residues provides an excellent energy source and an environmental friendly combustible fuel. This actually prompted this present studies which is aimed at comparing the calorific values of briquettes produced from some available agricultural residues (Idah \& Mopah, 2013). It was also observed that the higher the compaction pressure, the higher the density. From this result, it is evident that the briquetting process has been able to obtain increased density, which is a valuable factor in briquetting. Calorific values maximize with higher density and suitable for efficient transportation and safe storage. An increase in the maximum density was observed at all particle sizes, as pressure increased (Oladeji, \& Enweremadu, 2012).

\section{CONCLUSION}

The present study indicated that calorific values of all wastes were showed higher as compare to their respective raw material. The differences of calorific value of briquettes from coconut husks and raw were found highest $1460 \mathrm{kcal} / \mathrm{kg}$ followed by paddy straw $1070 \mathrm{kcal} / \mathrm{kg}$, groundnut shell $530 \mathrm{kcal} / \mathrm{kg}$ and sugar cane bagasse $384 \mathrm{kcal} / \mathrm{kg}$. The minimum differences were found in cotton husk $100 \mathrm{kcal} /$ $\mathrm{kg}$. Briquetting production is the best technique to use agricultural wastes.

\section{ACKNOWLEDGEMENT}

The author would like to thanks to Forest College and Research Institute, Mettupalayam (Tamil Nadu) and Bioenergy Department, College of Agriculture, Tamil Nadu Agriculture University (Tamil Nadu), Coimbatore, India for their support and appreciation for this work.

\section{REFERENCES}

Bhattacharya, S.C. (1989). State of the art for biomass densification energy sources. Taylor \& Francis, 11, 161-182.

Idah, P. A1, Mopah, E. J. (2013). Comparative assessment of energy values of briquettes from some agricultural by-products with different binders. IOSR Journal of Engineering, 3(1), 36-42.

Ioannis, G., Panagiotis, X., Dimitrios, K., Theodoros, G., Dimitrios, B. \& Kyriakos, G. (2016) Experimental determination of gross calorific value of different agroforestry species and bio-based industry residues. Natural Resources, 7(1), 57-68.

Hirsmark, J. (2002). Densified biomass fuels in Sweden: Country report. The EU/INDEBIF project. Swedish University of Agricultural Sciences, Uppsala.

Hood, A. H. (2010). Biomass briquetting in Sudan: A feasibility study. The United States Agency for International Development (USAID) and the Women's Refugee Commission.

Nicholas, A. M. (2012). Determination of chemical compositions, heating value and theoretical parameters of composite agricultural waste briquettes. International Journal of Scientific \& Engineering, 3(6), 1-5.

Nurdin, H., Hasanuddin, H, Darmawi, D., \& Prasetya, F. (2018). Analysis of calorific value of Tibarau cane briquette. IOP Conf. Series: Materials Science and Engineering 335 -012058.

Obi, F. O., Busayo S. A. \& Aneke, N. N. (2014). Biomass briquetting and rural development in Nigeria. International Journal of Sciences, Environmental and Technology, 3( 3), 1043 - 1052.

Obi, O. F., Akubuo, C. O., \& Okonkwo, W. I. (2013). Development of an appropriate briquetting machine for use in rural communities. International Journal of Engineering and Advance Technology, 2(4),578-582.

Oladeji, J. T., \& Enweremadu, C. C. (2012). The effects of some processing parameters on physical and densification characteristics of corncob briquettes. International Journal of Energy Engineering, 2(1), 22-27.

Onukak, E. I., Ibrahim, A. M., Alewo, O. A., Stanley, I. R. O., \& Opeoluwa O. F. (2017). Production and characterization of biomass briquettes from tannery solid waste. Recycling, 2(17), 1-19. 
Parr Instrument Company. (2013). Introduction to bomb calorimetry. Parr Instrument Company. Illionis, USA retrieved from https:// www.parrinst.com/wp-content/uploads / downloads/2013/07/483M_Parr_Intro-toBomb-Calorimetry.pdf.

Quartey, E. T. (2011). Briquetting agricultural waste as an energy source in Ghana. In Proceeding Recent researches in environment, energy planning and pollution. WSEAS Press, Romania.

Raju, C. A. I. , Ramya, J. K., Satya, M., \& Praveena, U. (2014). Studies on development of fuel briquettes for household and industrial purpose. International Journal of Research in Engineering and Technology, 3(2), 54-63.

Patil, G., Kumar, S., \& Dhixya, D. K. R. (2012). Economics of briquette production using forest residue and wood based industrial waste. Plant Arcbives, 12(2), 725-730.

Sainu, F., Venkata, R., \& Rao, M. K. R. M. (2017). Urbanization, energy consumption and emissions in the Indian context A review. Renewable and Sustainable Energy Reviews, 71, 898-907.

Sengar, S. H., Mohod, A. G., Khandetod, Y. P., Patil, S. S., \& Chendake, A. D. (2012). Performance of briquetting machine for briquette fuel. International Journal of Energy Engineering, 2(1), 28-34.
Surajo, N. \& Mustapha, A. (2017). Construction of a moulder and production of biomass briquette from bagasse for use as a fuel. International Journal of Scientific Research Engineering \& Technology, 6(9), $2278-0882$.

Shukla, S. \& Vyas, S. (2015). Study of biomass briquettes, factors affecting its performance and technologies based on briquettes. Journal of Environmental Science, Toxicology and Food Technology, 9(11), 37-44.

3e Savers India LLP. (2018). Biomass Briquettes. 3e Savers India LLP retrived from http://3esavers.in/biomass-briquettesproduct.html

Tripathy, A. I., Kandpal, P. V. R., \& Chandra, T. (1998). A techno-economic evaluation of biomass briquetting in India. Biomass and Bioenergy, 14(5/6), 479-488.

Tumuru, J. S., Sokhansanji, L. C. J., Bi, T., Lau, A., Melin, S., Sowlati, T., \& Oveisi, E. (2010). Quality of wood pellet produced in British Columbia for export. Applied Engineering Agriculture, 26, 1013-1020. 